\title{
HANDLING TECHNIQUE TO INCREASE THE HYACINTH MACAW POPULATION (Anodorhynchus hyacinthinus) (LALHAM, 1720) - REPORT OF AN EXPERIENCE IN PANTANAL, BRAZIL
}

\author{
KUNIY, A. A. ${ }^{1}$, FIGUEIREDO, I. C. S. ${ }^{2}$ and GUEDES, N. M. R. ${ }^{3}$ \\ ${ }^{1}$ Hyacinth Macaw Project Biologist, R. Américo Brasiliense, 615, CEP 04715-003, SP, Brazil \\ ${ }^{2}$ PPG Ecologia, UnB. SQN, 405, bloco G, apto. 107 \\ ${ }^{3}$ Hyacinth Macaw Project Coordinator, R. Klaus Sturhk, 178, CEP 79051-660, MS, Brazil \\ Correspondence to: Adriana Akemi Kuniy, Hyacinth Macaw Project Biologist, \\ R. Américo Brasiliense, 615, CEP 04715-003, São Paulo, SP, Brazil, \\ e-mail: araradri@ig.com.br
}

Received June 25, 2004 - Accepted December 6, 2004 - Distributed February 28, 2006

Habitat destruction and illegal bird trading are the main threats to most endangered species of psittacidae (Snyder et al., 1992; Stoleson \& Beissinger, 1997), including the hyacinth macaw (Anodorhynchus hyacinthimus Lalham, 1720). This species belongs to Brazil's list of endangered animals (IBAMA, 2003) and according to IUCN (The World Conservation Union, 2002) "there is a high risk of extinction in the wild in the medium term due to population decline and extremely fragmented occurrence area". Moreover, the species' biology and behavior tend to make the conservation of wild populations even more difficult (Stoleson \& Beissinger, 1997; Snyder et al., 1992). One of its traits is asynchronous hatching, which usually leads to brood size reduction due to the death of the youngest nestling (Stoleson \& Beissinger, 1999; 1997).

Among the alternatives to increase psittacidae populations, management programs can work to increase: a) the number of breeders by supplementing food or nest boxes; b) the proportion of successful breeders by building predator-safe nest boxes; and c) the number of young fledged per nest by adding more nest sites, providing supplemental food or forcing double clutching (Beissinger \& Bucher, 1992a; 1992b). This paper focuses on the third management action, which complements the activities of the Hyacinth Macaw Project (WWF Brazil, 2001), known for the implementation of more than 150 artificial nests and recovery of natural ones.

The current work's objective is to report the experience of artificial nursing and subsequent translocation of an A. hyacinthinus nestling, and to discuss the implications of this technique for an increment in the hyacinth macaw's wild population.

This experiment was conducted at the headquarters of the Hyacinth Macaw Project located in the southern Pantanal wetlands, state of Mato Grosso do Sul, Brazil. An egg was found abandoned in an artificial nest located in a ximbuva tree (Enterolobium contortisiliqum) and, after being kept in the laboratory, the young was successfully introduced into a natural nest cavity which already contained a nestling of the same age. Both nestlings were cared for normally by the parents and fledged the nest normally.

Some birds can determine the beginning of the development of their eggs and the synchrony of their hatching as they establish the beginning of the incubation. If the incubation begins before the last egg is laid, the development of the eggs and their hatching pattern will be asynchronous (Stolenson \& Beissinger, 1997; 1995; Clark \& Wilson, 1981). This phenomenon has been intriguing researchers for decades, as it presents a paradox: the parents' behavior produces a hatching pattern which normally causes the death of the youngest nestling (Stolenson \& Beissinger, 1999).

Several explanations for the adaptive value of asynchronous hatching have been proposed, including 17 hypotheses (Stolenson \& Beissinger, 1995). Stoleson \& Beissinger (1997) believe that the hatching asynchrony in macaws, including the Anodorhynchus gender, appears to have an insurance function (Insurance Hypothesis), since 
the last egg laid serves to replace unsuccessful earlier eggs or chicks that fail (Stoleson \& Beissinger, 1995). This hypothesis explains why some species necessarily lay more eggs than they can normally fledge (opus cit.).

For this reason, Beissinger \& Bucher (1992a; 1992b) suggest that, when the older chick survives, the surplus young or the last eggs laid can be managed without negative effects to the population, as they would have a low probability of survival in natural conditions and would otherwise be considered wasted potential productivity (Stolenson \& Beissinger, 1997).

The development of a management program to raise the last laid eggs or youngest chicks of hyacinth macaws may be a good option for conservation, since it can lead to a meaningful population increase, and to the development of a sustained harvest program (Stolenson \& Beissinger, 1997). To this end, reproductive and behavioral studies should be conducted to determine ideal parents for the reintroduction, ideal captivity conditions and techniques for handling young birds. Studies aimed at elucidating how hatching asynchrony works for this species are also necessary. In conclusion, the positive results of this experiment indicate its relevance for inclusion in a set of conservation measures for the long-term increase of wild populations of the Hyacinth macaw.

Acknowledgments - We would like to thank Carlos Yamashita, Cristiane Villaça, Eduardo Pereira C. Gomes, Pedro Develey and Larissa Schneider for their suggestions and encouragement, and Scott H. Stoleson for the references.

\section{REFERENCES}

BEISSINGER, S. R. \& BUCHER, E. H., 1992a, Can sustainable harvesting conserve parrots? BioScience, 42: 164-173.

BEISSINGER, S. R. \& BUCHER, E. H., 1992b, Sustainable harvesting of parrots for conservation, pp. 73-115. In: S. R. Beissinger and N. F. R. Snynder, editors. New World parrots in Crisis: Solutions from conservation biology. Smithsonian Institution Press, Washington, D. C.

CLARK, A. B. \& WILSON, D. S., 1981, Avian breeding adaptations: hatching asynchrony, brood reduction and nest failure. Q. Rev. Biol., 56: 253-277.

IBAMA, 2003, Lista Oficial de Fauna Ameaçada de Extinção. Instrução Normativa MMA, n 3 de 27 de Maio de 2003.

IUCN, The World Conservation Union, 2002, Red List. www.iucn.org.

SNYDER, N. F. R., JAMES, F. C. \& BEISSINGER, S. R., 1992, Toward a Conservation Strategy for Neotropical Psittacines, pp. 257-276. In: S. R. Beissinger \& N. F. R. Snynder, editors. New World parrots in Crisis: Solutions from conservation biology. Smithsonian Institution Press, Washington, D. C.

STOLENSON, H. S \& BEISSINGER, S. R., 1995, Hatching asynchrony and the onset of incubation in birds, revisited: When is the critical period? Current Ornithol, 12: $191-270$

STOLENSON, H. S. \& BEISSINGER, S. R., 1997, Hatching asynchrony in parrots: Boon or bane for sustainable use? pp. 157-180. In: J. R. Clemmons \& R. Buchholz (eds). Behavioral Approaches to Conservation in the Wild. Cambridge University Press, Cambridge, U. K.

STOLENSON, H. S. \& BEISSINGER, S. R., 1999, Egg viability as a constraint on hatching asynchrony at high ambient temperatures. Journal of Animal Ecology, 68: 951-962.

WWF BRASIL, 2001, Projeto Arara Azul - Relatório Técnico, www.bluemacaws.org. 